\title{
曲げ振動疲労試験機を用いた高周波重畳波浪荷重 を受ける溶接継手の疲労強度に関する研究
}

\author{
正会員 大 沢 直 樹 ${ }^{*}$ 正会員 中 村 哲 也 ** $^{* *}$ \\ 正会員 山本 規 雄 ${ }^{* * *}$ 正会員 澤 村 淳 司 ${ }^{*}$
}

Study on Fatigue Strength of Welded Joints Subject to High Frequency Superimposed Wave Loadings by Using Plate-Bending-Vibration Type Fatigue Testing Machines

by $\quad$ Naoki Osawa, Member

Tetsuya Nakamura, Member

Norio Yamamoto, Member Junji Sawamura, Member

\begin{abstract}
Summary
Plate-Bending-Vibration (PBV) type fatigue testing machines, which can carry out fast and low-cost fatigue tests of welded joints subject to wave loads with high frequency vibration, have been developed. These machines are designed for plate bending type fatigue tests, and wave load is applied by using motors with eccentric mass. Springing vibration is superimposed by attaching an additional vibrator to the test specimen, and whipping vibration is superimposed by hammering. PBV machines can drastically reduce the testing time and the electricity to be used for high frequency superimposed fatigue tests. It is found that the fatigue life under constantly high frequency superimposed loads can be predicted with acceptable accuracy by the modified Miner rule when rainflow stress counting is performed and $\mathrm{S}-\mathrm{N}$ curve is modified so that it fits the equivalent stress range's $\mathrm{Ps}=50 \%$ curve. It has also been found that the fatigue lives are prolonged substantially than estimated when the high frequency components are superimposed intermittently. This means that the application of Miner rule to rainflow counting might lead to over conservative estimates under real stress sequences in which springing and whipping occur intermittently. The validity of rainflow counting method should be further examined by carrying out fatigue tests with realistic stress histories which emulate intermittent occurrence of springing and whipping in ship structure.
\end{abstract}

\section{1. 緒言}

近年のコンテナ船の長大化に伴い, スプリンギングやホイ ッピング等の高周波振動が疲労強度に及ぼす影響が問題に なっている.この問題は荷重評価分野での議論が先行してい

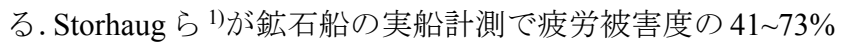
が振動成分に由来していたと報告して以来, 実船計測が多数 実施され, 大型コンテナ船等では振動成分の寄与比率が $50 \%$ を超えるとの報告が相次いだ(例えば Storhaug ら $\left.{ }^{2}\right)$ ）。これ らの解析では, rainflow 法により疲労寿命が評価されている. 弾性振動が疲労強度に与える影響 (以下で高周波影響とよぶ) を合理的に評価するためには, 船舶に作用する重畳波形を受 ける溶接継手の疲労強度を rainflow 法で評価することの有 効性について検証しなければならない.

以下で, 波浪変動荷重を模擬した低周波荷重を一次波また は Low Frequency Wave (LFW) とよび, 一次波に重畳する高 周波荷重を二次波または High Frequency Wave (HFW) と呼ぶ.

\footnotetext{
* 大阪大学大学院工学研究科

**ジャパン・マリンユナイテッド（株）

*** (一財) 日本海事協会技術研究所
}

原稿受理 平成 27 年 8 月 1 日
機械分野では，高周波影響に関する研究が 1970 年代を中 心に多数実施された例えば 3)-7). 著者らの調査した範囲では, これらの先行研究は全て母材の疲労試験であり溶接継手を 対象とした研究例はなかった.これらの研究では, 炭素鋼 3)6), $\mathrm{Cr}-\mathrm{Mn}$ 鋼 ${ }^{4)}, \mathrm{Ni}-\mathrm{Mo}$ 鋼 ${ }^{5)}$, 鋳鉄 ${ }^{7)}$ 等を対象に, 各種応力力ウ ント法の有効性や一次 -二次波の周波数比・振幅比や平均応 力の影響などが調査された。これらの報告を比較すると, 材 料, 負荷様式, 荷重パターンが変わると大きく異なる結果が 得られており，一般的傾向を見出すことができない.すなわ ち,一般性のある高周波影響の評価手法は未だ確立されてい ない. この事実は, 船舶海洋構造物の溶接継手に有効な評価 法は, 実機が遭遇する応力波形パターンを使用し, 実機の材 料・構造詳細を再現した実験・解析に基づいて構築する必要 があることを示している。

船舶海洋工学分野では 2013 年頃から高周波影響に関する 研究が行われている. 日本国内では, 主としてホイッピング 重畳荷重下の母材中の疲労き裂伝播挙動が調べられた. 北村 $5^{8)}$ は高周波重畳荷重下のき裂伝播試験を実施して rainflow 法に基づく疲労被害度計算の有効性を検討した。角 9), Sumi ${ }^{10)}$ は疲労き裂伝播に対するホイッピング成分の加速影 響や, 重畳波形と等価な伝播挙動を与える等価一次波応力範 囲の決定法について考察した. Gotoh ら 11), 後藤ら ${ }^{12)}$,

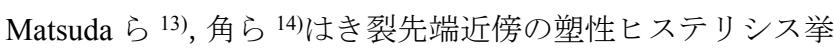


動に着目し, 疲労き裂進展に有効に寄与する荷重履歴の抽出 手法を提案した.

機械分野の先行研究の調査結果は，母材中き裂伝播の計 測・解析で得られた知見の実機（溶接継手）での有効性は, 溶接継手試験体を使用し, 実機が遭遇する荷重を模擬した多 数の荷重ケースで高周波重畳疲労試験を実施して確認する 必要があることを示している. そのような溶接継手疲労試験 例は Fricke ら 15)，Kahl ら 16)のみしかない，彼らは油圧試験 機によりホイッピング重畳波形を模擬した応力履歴を受け る十字溶接継手（板厚 $12 \mathrm{~mm}$ ）の疲労試験を実施し，ホイッ ピング重畳荷重下の破断時疲労被害度が $0.5 \sim 1.0$ と計算され たと報告している。しかし, Fricke ら ${ }^{15)}$, Kahl ら ${ }^{16)}$ の試験 点数, 荷重ケース数は, 一般性のある結論を導くには不十分 である。

溶接継手の高周波疲労試験の実施例が稀少なのは, 油圧サ 一ボ疲労試験機で高周波重畳応力波形を再現寸る場合の運 転費用（特に電気料金）と試験時間が許容限度を超えて大き いためである。そこで本研究では, 溶接継手の高周波重畳疲 労試験に要する費用・時間を劇的に削減できる新しい疲労試 験装置を開発する。 そして, スプリンギング重畳疲労試験と ホイッピング重畳疲労試験を実施して試験に要する運転費 用・時間を従来装置と比較し, 開発装置の有効性と優位性を 示す．また，高周波成分による振幅増大効果のみを評価する enlargement 応力カウント法（以下で enlargement 法とよぶ） を開発し, 開発法と rainflow 法で応力範囲ヒストグラムと疲 労被害度にどのような差が生じるかを調べる. 続いて, 得ら れた疲労試験結果と応力カウント結果から, 定常的に高周波 が重畳する場合の疲労寿命評価手法の構築を試みる.さらに, 高周波が間欠的に重畳する応力波形を負荷した疲労試験を 実施し, 定常的重畳試験結果に基づく寿命推定法の間欠的重 畳波形に対する有効性を調べる.

\section{2. 回転偏心鍾を用いた疲労試験装置}

Yamada $^{17)}$ は，回転偏心錘を電気モータで駆動する市販起 振機を用いた, 簡便な疲労試験装置を開発し, 種々の荷重形 態で溶接継手の疲労試験を実施した. Yamada の試験装置を 使用すると, 多様な板厚・寸法の試験体で荷重周波数 $20 \mathrm{~Hz}$ 以上の高速度負荷を容易に実現でき, 試験に要する電気料金 を従来型油圧試験装置を使用する場合の $1 / 1000$ 以下に削減 できる。

Fig. 1 に板曲げ振動型試験装置の構成と回転起振機の写真 を示す. 装置はフレームに片持ち梁として固着された試験体 と, 回転起振機, 起振機制御装置, スプリングから構成され る．以下でこの装置を Plate Bending Vibration, PBV 試験機と よぶ. 試験中の荷重は試験体に取付けた歪ゲージの出力から 間接的に計測する. 平均応力は，スプリングにより片持ち梁 自由端に死荷重を加えて負荷する. 従来型油圧サーボ試験機 と PBV 試験機の試験条件および運転費用の比較例を Table 1
に示す.

従来型試験機では, 試験体の変位がアクチュエータで拘束 されるため試験体は自由に振動できない。一方，PBV 試験 機では, 一次波荷重を加えていても試験体の弾性振動は拘束 されない. よって, PBV 試験機に高周波数の起振機を追加 すればスプリンギング重畳荷重を, 試験体を打撃して減衰す る弾性振動を生じさせればホイッピング重畳荷重を負荷す ることができる.後者の場合, 一次波振動数は自由に設定で きるが, ホイッピング振動の周波数は試験体の曲げ固有振動 数(Bending Natural Frequency, BNF)に固定される.

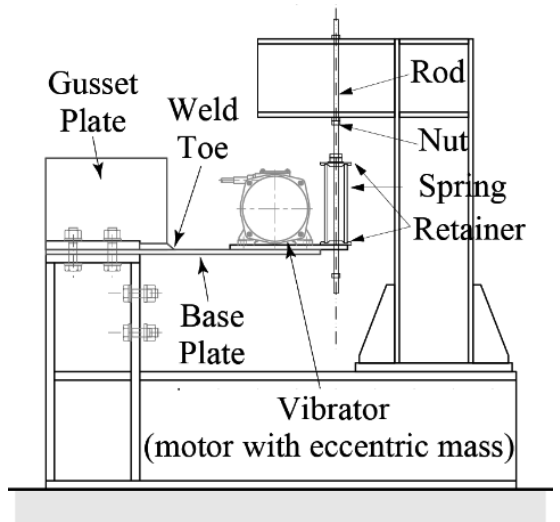

(a) Apparatus configuration and setup of out-of-gusset weld joint specimen.

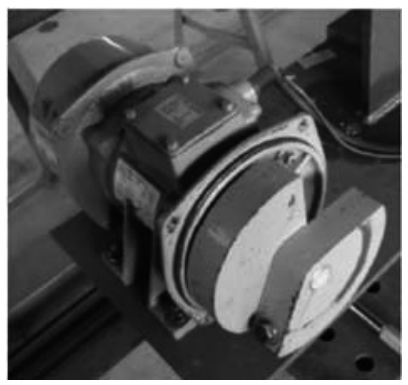

(b) Motor with eccentric mass.

Fig. 1 Plate Bending Vibration (PBV) type fatigue testing machine.

Table 1 An example of running costs of PBV-type and conventional testing machines.

\begin{tabular}{|l|l|l|}
\hline & Conventional machine & \multicolumn{1}{|c|}{ Develped machine } \\
\hline Power source & Hydraulic pressure & Electric motor \\
\hline Load application & Load, Displacement & Inertia force \\
\hline Load frequency & about $2 \sim 3 \mathrm{~Hz}$ & $20 \mathrm{~Hz}$ \\
\hline $\begin{array}{l}\text { Electricity } \\
\text { expense per } \\
\text { specimen }\end{array}$ & $\begin{array}{l}65,000 \mathrm{JPY} \\
\text { (650USD) }\end{array}$ & $\begin{array}{l}60 \mathrm{JPY} \\
(0.60 \mathrm{USD})\end{array}$ \\
\hline
\end{tabular}

\section{3. 高周波重畳疲労試験装置}

\section{1 スプリンギング重畳荷重}

スプリンギング振動は，PBV 試験装置の試験体に追加起 振機を取付けて発生させた．Fig. 2 に装置の写真を示す。一 次波と二次波（スプリンギング荷重）の周波数は別個に制御 
され, 荷重振幅は各起振機の錘の偏心度と起振機の取付け位 置を変えて調整した。

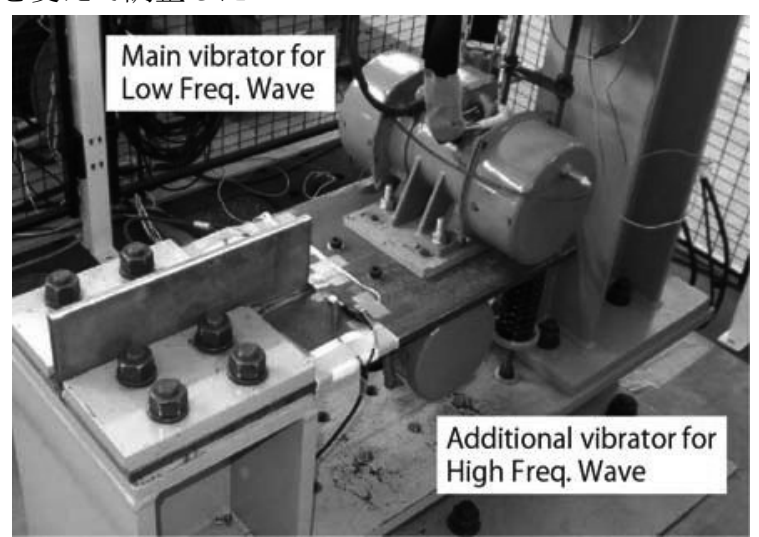

Fig. 2 The PBV-type testing machine with additional vibrator used in springing superimposed loading tests.

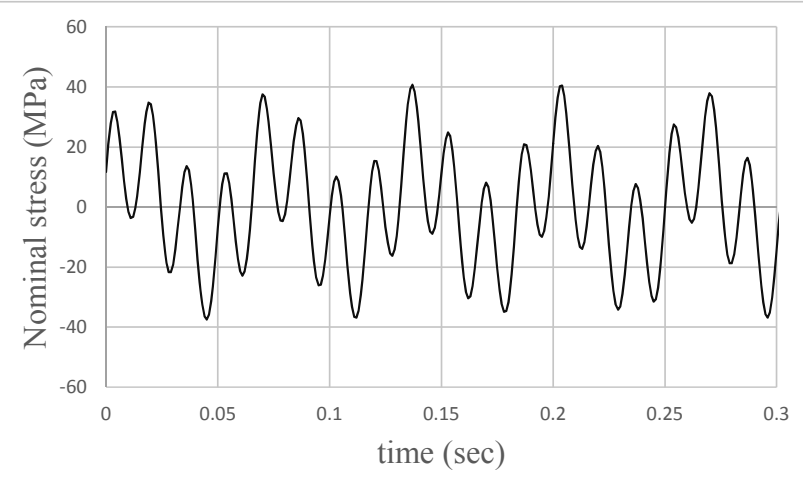

Fig. 3 An example of stress wave forms with springing vibration.

荷重の周期, 角振動数, 公称応力範囲を, 二次波について $\mathrm{T}_{\mathrm{HF}}, \omega_{\mathrm{HF}}, \Delta \sigma_{\mathrm{HF}}$ と, 一次波について $\mathrm{T}_{\mathrm{LF}}, \omega_{\mathrm{LF}}, \Delta \sigma_{\mathrm{LF}}$ と表す．応 力時刻歴の例を Fig. 3 に示す。この場合 $\omega \mathrm{HF} / \omega \mathrm{LF}=3.78$, $\Delta \sigma_{\mathrm{HF}} / \Delta \sigma_{\mathrm{LF}}=0.74$ である.

この試験装置により実施した 7 体の試験体を使用したス プリンギング重畳荷重疲労試験に要した時間は付帯作業を 含めて 5 日間, 電気料金は全体で約 250 円であり, 試験に要 する時間と費用の劇的な削減効果が実証された.

\section{2 ホイッピング重畳荷重}

Toyoda et al. ${ }^{18)}$ は，コンテナ船で高周波重畳荷重の実船計 測を行い，ホイッピング重畳荷重の特徵について，a) ホイ ッピング振動は一次波の約 5 倍の周波数で生じていたこと, b) ホイッピング振動は一次波 5 波で概水減衰したこと，を 報告した。

本研究では, この特徵をもつ応力波形を模擬できる試験装 置を開発した. ホイッピング振動は試験体の自由端を回転八 ンマで打撃して発生させた. ハンマ打撃は一次波 5 波につき 1 回行った。一次波発生用起振機の回転軸に取付けたエンコ 一ダで偏心錘の位置を検知し, 錘が規定の位置にあるとき八 ンマが打撃するよう制御した。これにより一次波と二次波 （ホイッピング振動）の位相差が一定に保たれる. Fig. 4 に 打撃装置の全体構成および回転ハンマの写真を示す.

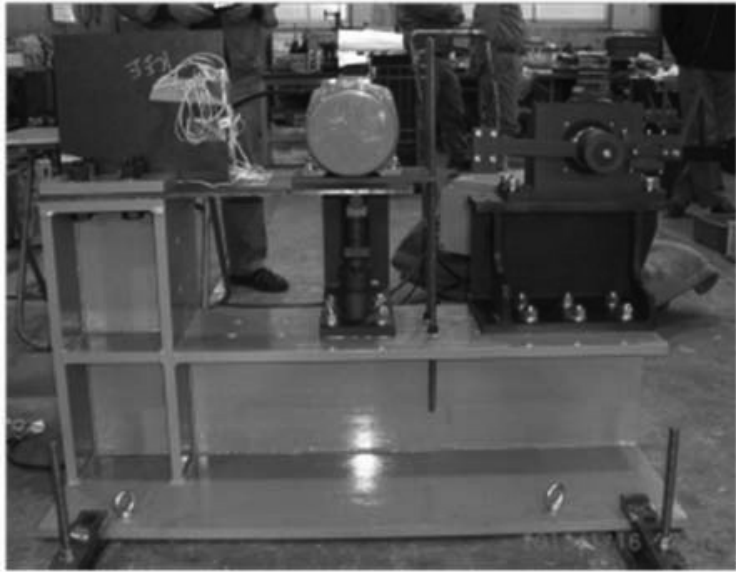

(a) General view.

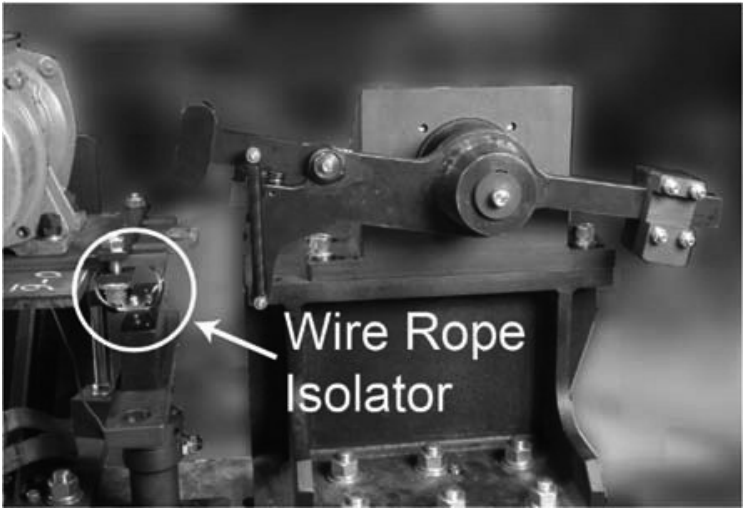

(b) Rotation hammer and wire rope isolator.

Fig. 4 The rotation hammering apparatus used in whipping superimposed loading tests.

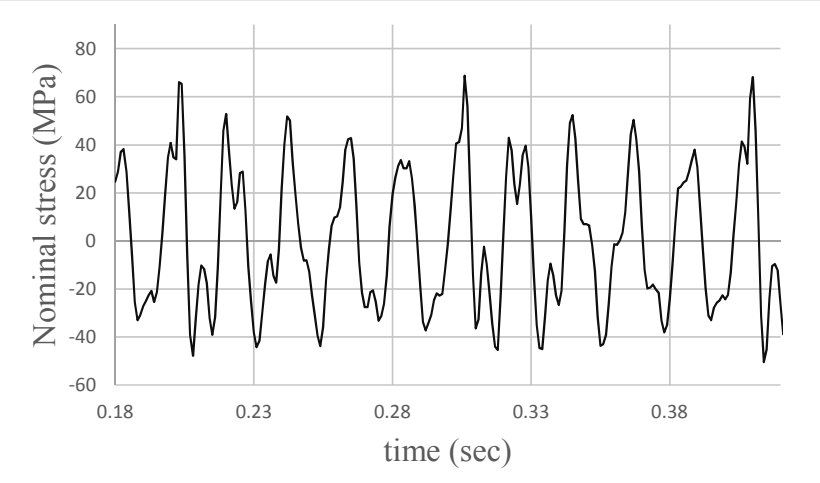

Fig. 5 An example of stress waveforms with whipping vibration.

ホイッピング振動数は試験体の BNF に等しく, 本研究で 使用した $12 \mathrm{~mm}$ 板厚試験体で約 $28 \mathrm{~Hz}$ である. 衝撃力はハン マヘッドの重量を変えて調整し, 減衰能は試験機フレームと 試験体の間に挿入したワイヤーロープ型ダンパ(Enidine CR シリーズ)の容量を変えることで制御した。一次波振動数は BNF の概ね 1/3〜1/4 とした.

Fig. 5 にホイッピング重畳応力波形の例を示す．この例で $\mathrm{BNF}$ は約 $28 \mathrm{~Hz}$ ，一次波周波数は $7 \mathrm{~Hz}$ である，図では，開発 装置により意図したホイッピング重畳応力波形を発生でき ることが示されている。 
本研究では, ASTME 1049-85 19)に準拠した rainflow 法の他 に, 高周波成分を無視して一次波成分の応力範囲と周期によ り計数を行う LFW(Low Frequency Wave)カウント法, 高周波 による振幅拡大効果のみ考慮する enlargement 法により疲労 被害度を計算した。

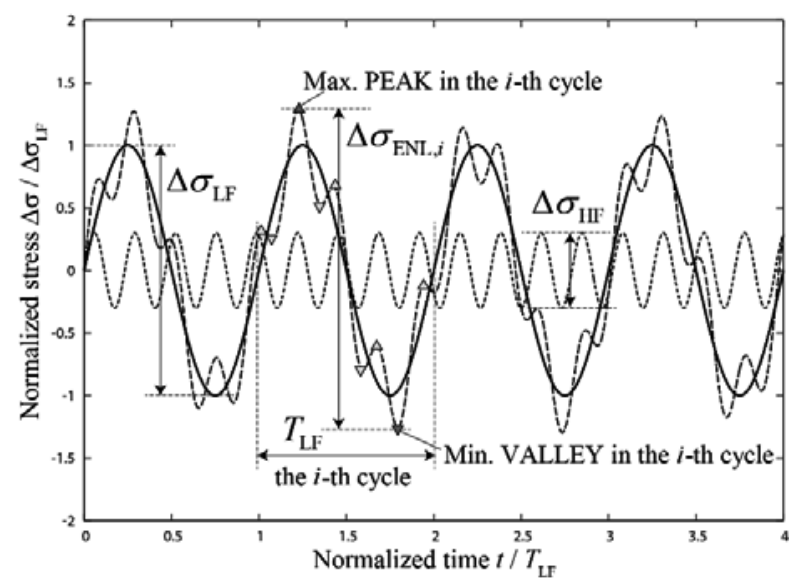

Fig. 6 Definitions of enlarged stress range.

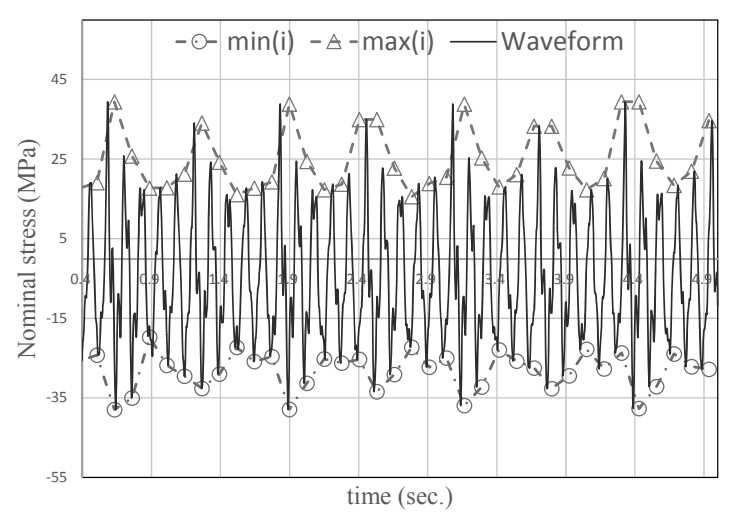

Fig. 7 An 'envelope' waveforms determined by enlarged stress ranges.

enlargement 法の計算手順を以下に示す.

a) 歪が極大・極小になったときの時刻と歪に関する記録を 作成する.

b) 極大・極小值データを一次波周期 $\mathrm{T}_{\mathrm{LF}}$ (本報の実験では一 定)毎に分割し，各区分が一次波 1 サイクルと考える.

c) 第(i) 一次波サイクル中の極大值の中の最大值 $\max (i)$ と極 小值の中の最小值 $\min (\mathrm{i})$ を記録する.

d) 第(i) 一次波サイクルの peak-to-peak 範囲 $\Delta \sigma_{E N L, i}$ を $\Delta \sigma \mathrm{ENL}, \mathrm{i}=\max (\mathrm{i})-\min (\mathrm{i})$ と評価する.

enlarged counting における $\Delta \sigma_{\mathrm{ENL}, \mathrm{i}}$ と $\mathrm{T}_{\mathrm{LF}}$ の定義を Fig. 6 に 示す. 疲労被害度は, 振幅 $\Delta \sigma E N L, i$, 周期 $T_{L F}$ の応力波形を想 定して計算した.

各一次波サイクルの $\max (\mathrm{i})$ どうし, $\min (\mathrm{i})$ どうしを結んだ 線図と,ホイッピング重畳波形を比較した例を Fig. 7 に示す. $\max (i), \min (i)$ は一次波周期終端に值が確定するので, これら のグラフは時刻（横軸）が一次波周期終端にあるよう作図し
た.このため元波形の最大・最小荷重と $\max (\mathrm{i}), \min (\mathrm{i})$ の横方 向位置には最大で $T_{L F}$ の差が生じている，図では，同じ時刻 の $\max (\mathrm{i})-\min (\mathrm{i})$ が, それ以前の $\mathrm{T}_{\mathrm{LF}}$ の間のホイッピング重畳 波形の全振幅に一致していること,すなわち包絡線の全振幅 に相当していることが示されている.

\section{4. 疲労試験結果}

造船用鋼板 AH32 で作成した Fig. 8 の形状・寸法の角回し 溶接継手試験体の疲労試験を実施した. 試験体は図の左端を 固着し, 自由端に取付けた起振機で一次波を発生させた。

疲労き裂は主板中央線付近の角回し溶接ビード止端に発 生した.き裂はビード止端に沿って進展した後にビードから 離れて主板内に進入した，以下で，き裂がビードから離れた 時点の一次波負荷回数を $\mathrm{N}_{\mathrm{b}}$ とよび， $\mathrm{N}_{\mathrm{b}}$ を疲労寿命と定義す る. Fig. 8 に示す Ch1〜 4 の 4 点で主板表面の長手方向歪を 計測した. 溶接止端と歪ゲージ中央との距離は Ch1 で $5 \mathrm{~mm}$, $\mathrm{Ch} 2$ で $12 \mathrm{~mm}$ である. Ch3, Ch4 は付加板溶接線から側方に $75 \mathrm{~mm}$ 離して配置したので局所応力集中の影響は無視でき る. 本研究で実施した全ての疲労試験で, 試験体にスプリン グによる死荷重を与えなかった。 これは応力比がほぼ-1で あったことを意味する。

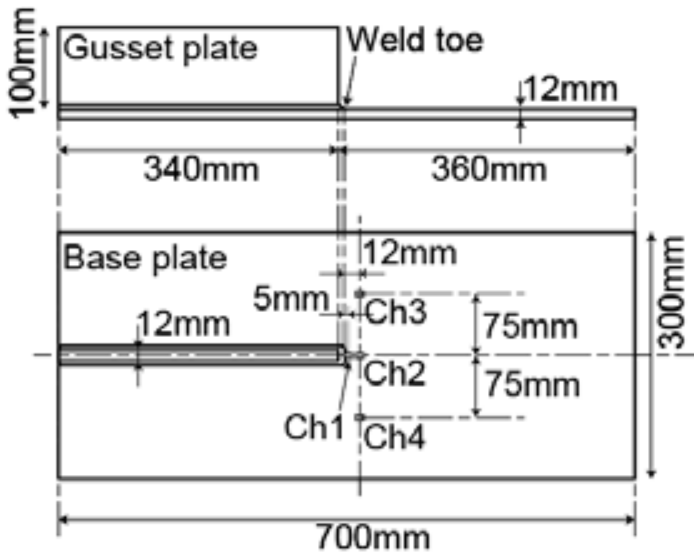

Fig. 8 Out-of-plane gusset welded joint specimen (unit:mm).

\section{1 定荷重疲労試験}

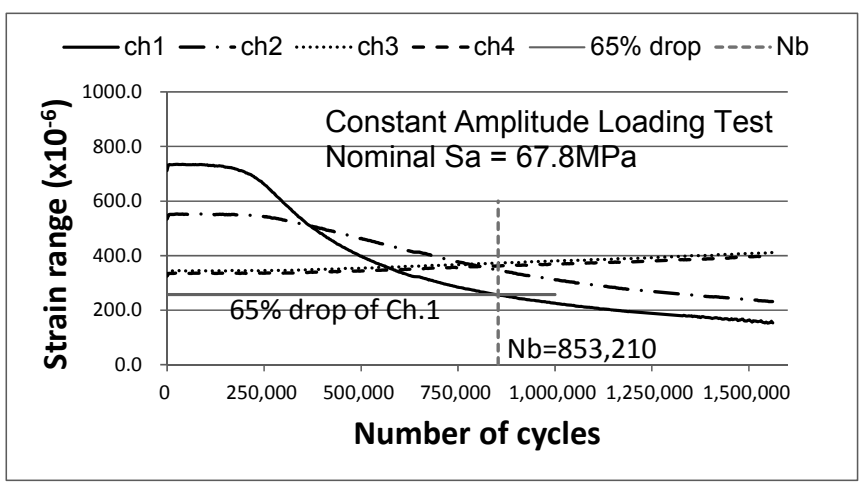

Fig. 9 Changes in strain amplitudes during a constant amplitude fatigue test $(\Delta \sigma=67.8 \mathrm{MPa})$. 
PBV 試験装置を使用して定荷重振幅疲労試験を実施した.

Fig. 9 に歪範囲履歴の例を示寸. 試験開始後約 25 万回ま で全 $\mathrm{Ch}$ で歪範囲が概ね一定值を保つが，その後局所応力集 中の影響を受ける Ch1, Ch2 で負荷回数につれて歪範囲が減 少する一方, 公称歪 $\mathrm{Ch} 3, \mathrm{Ch} 4$ では歪範囲が微増する。これ らの変化は, き裂の発生・進展による応力再配分で生じてい る. 以下で, 公称曲げ応力範囲を $\mathrm{Ch} 3, \mathrm{Ch} 4$ の初期歪範囲か ら計算する。

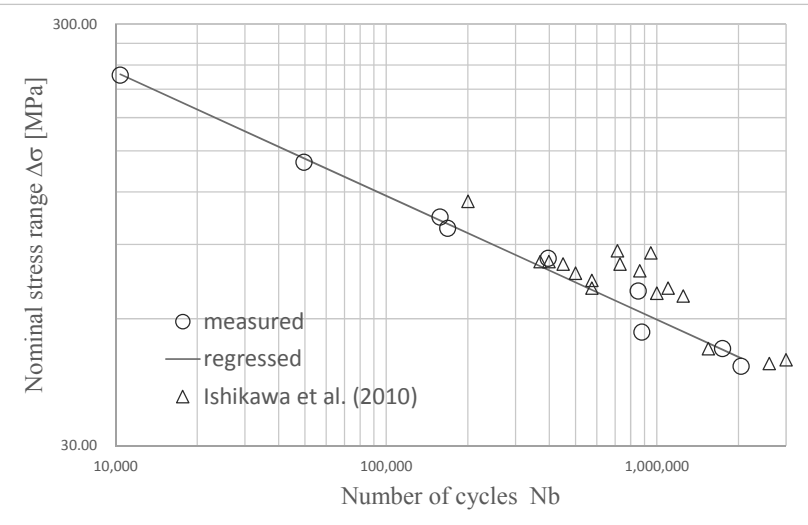

Fig. 10 Fatigue strength of out-of-plane gusset welded joints under constant amplitude loading tests (the relationship between nominal stress range and $\mathrm{N}_{\mathrm{b}}$ ).

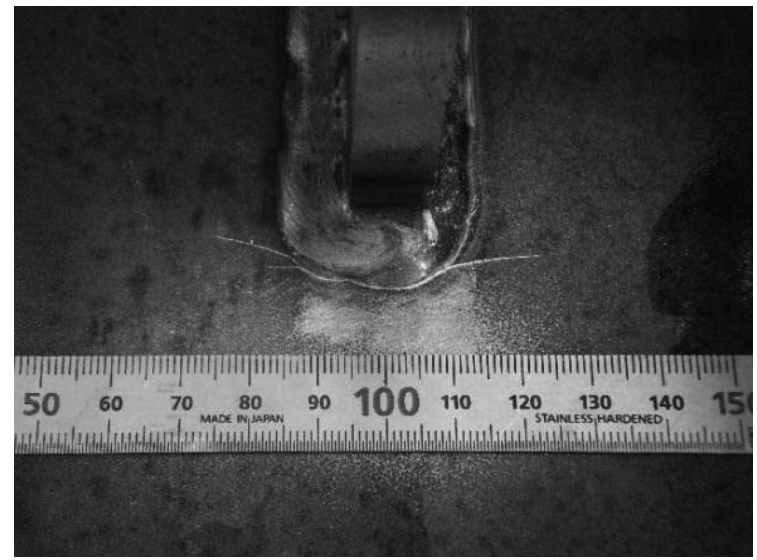

(a) Crack propagation path on the main plate surface.

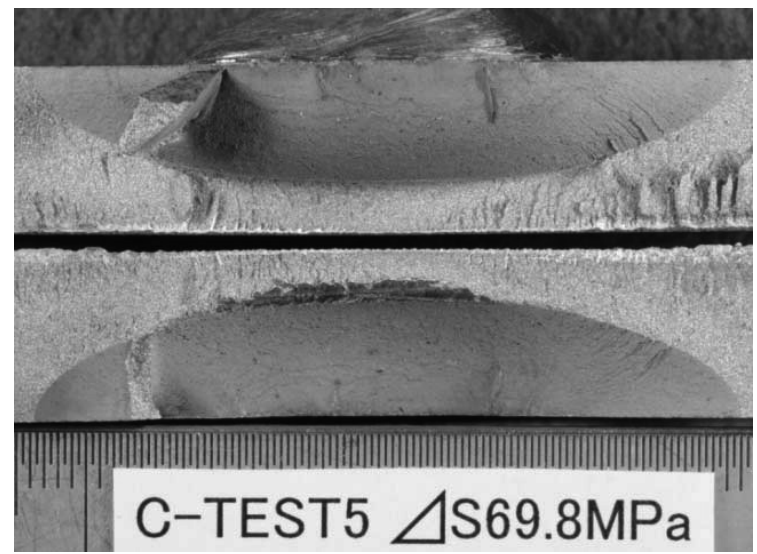

(b) Fracture surface.

Fig. 11 The fatigue crack at the weld toe observed in a constant amplitude test $(\Delta \sigma=69.8 \mathrm{MPa})$.
Fig. 9 の試験結果で，き裂の目視観察から決定した $\mathrm{N}_{\mathrm{b}}$ は $8.53 \times 10^{5}$ 回で,このとき Ch1 の歪範囲は初期振幅から約 $65 \%$ の低下を示した. 本研究で実施した定荷重振幅試験の全てで, $\mathrm{N}_{\mathrm{b}}$ において Ch1 歪範囲が約 $65 \%$ の低下を示した. よって, 本研究で実施した定荷重振幅疲労試験では, Ch1 歪範囲が初 期值から 65\%減少するまでの負荷回数を $\mathrm{Nb}$ として扱う.

以下では，本研究で実施した定荷重振幅試験の $\mathrm{N}_{\mathrm{b}}$ に関す る $\mathrm{SN}$ 線図により疲労被害度を計算する。この $\mathrm{SN}$ 線図にお ける Basquin の式

$$
\Delta \sigma=C N_{b}^{m}
$$

の比例係数・べき乗指数は $C=3.443 \times 10^{3} \mathrm{MPa}, m=-0.293$ で あった。

名古屋大学は Fig. 8 と同一形状の軟鋼 SM490 製試験体を 用いて Fig. 1 の PBV 試験機による定荷重振幅疲労試験を実 施し, 油圧試験機による疲労試験と同等の疲労強度が計測さ れたと報告した (石川ら $\left.{ }^{20)}\right)$. 本研究の試験結果と名古屋大学 の試験結果における公称応力範囲 $\Delta \sigma$ と $\mathrm{N}_{\mathrm{b}}$ の関係を Fig. 10 に示す. Fig. 10 では本研究の試験結果が名古屋大学の試験 結果のばらつきの範囲内にあったことが示されている．Fig． 11 に本研究の定荷重疲労試験で生じた疲労き裂の伝播経路 および破面マクロ写真を示す. Fig. 11(a)では, PBV 試験で, 油圧式疲労試験機を用いた場合と同様に, 止端中央に生じた き裂がビードに沿って進展した後主板に進入したことが示 されている。また，Fig. 11(b)のPVB 疲労試験の破面では， 油圧式疲労試験で通常観察される破面との顕著な差は認め られない, 以上の結果は，本研究で使用した PBV 試験装置 により, 油圧式試験機を用いた場合と同等な疲労試験結果が 得られることを示している.

\section{2 スプリンギング重畳疲労試験}

Fig. 2 に示すスプリンギング振動発生用追加起振機を搭載 した PBV 試験装置を使用して，スプリンギング重畳疲労試 験を実施した。試験条件を Table 2 に示す. 記号 S1, S2, S3 は 一次波応力範囲が $36 \mathrm{MPa}, 48 \mathrm{MPa}, 60 \mathrm{MPa}$ の試験シリーズで あることを示す．表中の $\Delta \sigma_{H F} / \Delta \sigma_{L F}$ and $/$ or $\Delta \sigma_{H F} / \Delta \sigma_{\text {env }}$ は二次 波 (スプリング) 応力範囲の一次波に対する相対的比率を表 す.

Table 2 Loading conditions, fatigue lives and accumulated damage of constantly springing superimposed loading tests.

\begin{tabular}{|l|r|r|r|c|c|c|c|r|r|}
\hline No. & $\begin{array}{r}\Delta \sigma_{\mathrm{LF}} \\
(\mathrm{MPa})\end{array}$ & $\begin{array}{r}\Delta \sigma_{\mathrm{HF}} \\
(\mathrm{MPa})\end{array}$ & $\begin{array}{r}\Delta \sigma_{\mathrm{HF}} \\
/ \Delta \sigma_{\mathrm{LF}}\end{array}$ & $\mathrm{Nb}$ & $\mathrm{D}_{\mathrm{LF}}$ & $\mathrm{D}_{\mathrm{ENL}}$ & $\mathrm{D}_{\mathrm{rf}}$ & $\begin{array}{c}\Delta \sigma_{\text {eq,ENL }} \\
(\mathrm{MPa})\end{array}$ & $\begin{array}{c}\Delta \sigma_{\text {eq,rf }} \\
(\mathrm{MPa})\end{array}$ \\
\hline S1-1 & 36.7 & 27.0 & 0.74 & $1.882 \mathrm{E}+06$ & 0.349 & 1.560 & 1.658 & 54.1 & 55.0 \\
\hline S1-2 & 35.6 & 33.6 & 0.94 & $7.210 \mathrm{E}+05$ & 0.121 & 0.859 & 0.957 & 60.4 & 61.6 \\
\hline S1-3 & 35.6 & 44.7 & 1.26 & $2.239 \mathrm{E}+05$ & 0.037 & 0.507 & 0.627 & 73.8 & 78.1 \\
\hline S2-1 & 47.6 & 28.0 & 0.59 & $4.910 \mathrm{E}+05$ & 0.221 & 0.881 & 0.936 & 68.9 & 69.8 \\
\hline S2-2 & 48.0 & 36.5 & 0.76 & $4.247 \mathrm{E}+05$ & 0.197 & 1.091 & 1.168 & 76.7 & 78.4 \\
\hline S2-3 & 47.8 & 55.2 & 1.15 & $1.518 \mathrm{E}+05$ & 0.069 & 0.837 & 1.014 & 96.6 & 101.9 \\
\hline S3-1 & 60.1 & 21.4 & 0.36 & $4.855 \mathrm{E}+05$ & 0.485 & 1.131 & 1.186 & 74.5 & 75.3 \\
\hline S3-2 & 62.8 & 12.2 & 0.19 & $6.515 \mathrm{E}+05$ & 0.756 & 0.984 & 1.009 & 65.4 & 65.8 \\
\hline S3-3 & 62.0 & 32.3 & 0.52 & $2.802 \mathrm{E}+05$ & 0.311 & 0.881 & 0.913 & 81.6 & 82.4 \\
\hline
\end{tabular}


疲労寿命 $\mathrm{N}_{\mathrm{b}}$ の計測值を Table 2 に示す. 疲労寿命は, $\Delta \sigma_{L F}$ が同程度の場合は $\Delta \sigma_{\mathrm{HF}}$ の増大につれて短くなっている.

rainflow 法, enlargement 法, LFW カウント法で計算した 疲労寿命 $\mathrm{N}_{\mathrm{b}}$ までの疲労被害度を $\mathrm{D}_{\mathrm{rf}}, \mathrm{D}_{\mathrm{ENL}}, \mathrm{D}_{\mathrm{LF}}$ と表す. 被害 度の計算では修正マイナー則を用いた， D $\mathrm{rf}, \mathrm{D}_{\mathrm{ENL}}$ から, 式(2) により等価応力範囲 $\Delta \sigma_{\mathrm{eq}, \mathrm{rf}}, \Delta \sigma_{\mathrm{eq}, \mathrm{ENL}}$ を計算した。

$$
\Delta \sigma_{\mathrm{eq}, \mathrm{rf}}=C\left(N_{b} / D_{\mathrm{rf}}\right)^{m}, \Delta \sigma_{\mathrm{eq}, \mathrm{ENL}}=C\left(N_{b} / D_{\mathrm{ENL}}\right)^{m},(2)
$$

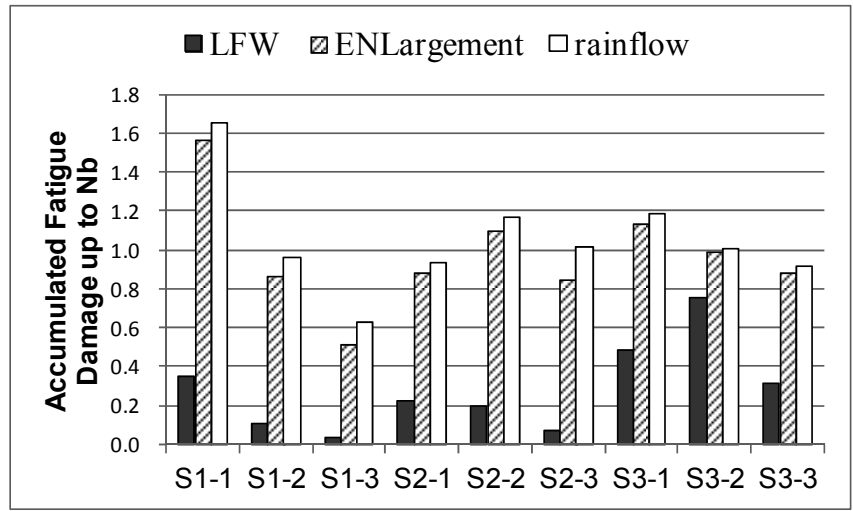

Fig. 12 Accumulated fatigue damage up to $\mathrm{N}_{\mathrm{b}}$ of out-of-plane gusset welded joints under springing superimposed wave loadings calculated by LFW, enlargement and rainflow counting methods.

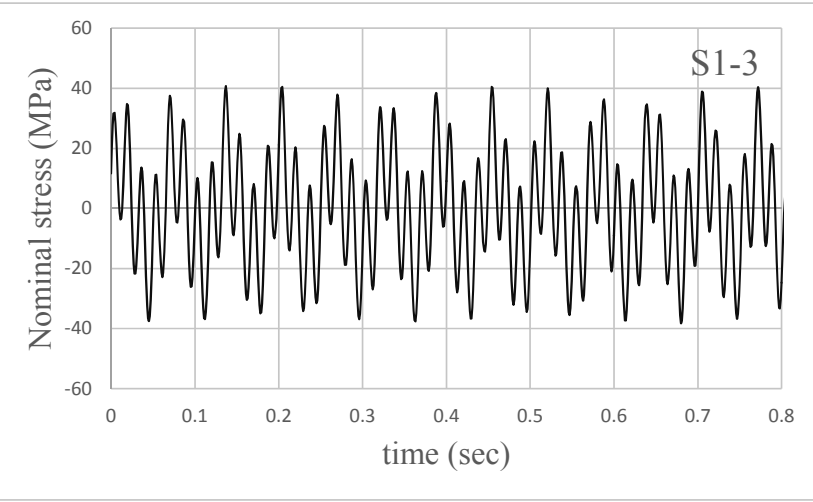

(a) Case S1-3: $\Delta \sigma_{\mathrm{LF}}=35.6 \mathrm{MPa}, \Delta \sigma_{\mathrm{HF}} / \Delta \sigma_{\mathrm{LF}}=1.26$

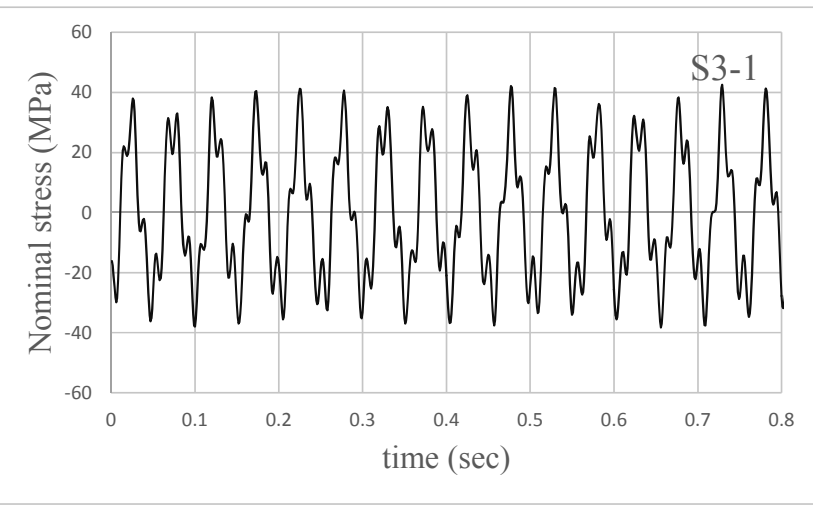

(b) Case S3-1: $\Delta \sigma_{\mathrm{LF}}=60.1 \mathrm{MPa}, \Delta \sigma_{\mathrm{HF}} / \Delta \sigma_{\mathrm{LF}}=0.36$

Fig. 13 Examples of nominal stress waveform generated in springing superimposed loading tests
ここで, $C$ と $m$ は式(1)の值を用いる. 各ケースの $\mathrm{D}_{\mathrm{rf}}, \mathrm{D}_{\mathrm{ENL}}$, $\mathrm{D}_{\mathrm{LF}}, \Delta \sigma_{\mathrm{eq}, \mathrm{rf}}, \Delta \sigma_{\mathrm{eq}, \mathrm{ENL}}$ の值を Table 2 に, $\mathrm{D}_{\mathrm{rf}}, \mathrm{D}_{\mathrm{ENL}}, \mathrm{D}_{\mathrm{LF}}$ の比較 を Fig. 12 に示す.

重畳試験中に計測した公称応力波形の例を Fig. 13 に示す. Fig. 13(a)では $\Delta \sigma_{\mathrm{HF}} / \Delta \sigma_{\mathrm{LF}}=1.26$ であり一次波より二次波の方 が応力範囲が大きく高周波成分が支配的である. Fig. 13(b)で は $\Delta \sigma_{\mathrm{HF}} / \Delta \sigma_{\mathrm{LF}}=0.36$ であり，支配的な一次波に高周波成分が重 畳した実船のスプリングに類似の波形になっている．Fig. 13(b)の波形について, rainflow 法, enlargement 法で波形分解 した応力範囲 $\Delta \sigma_{\mathrm{rf}}, \Delta \sigma_{\mathrm{ENL}}$ の発現頻度分布を Fig. 14 に示す.

これらの図表では以下が示されている：

a) $\Delta \sigma$ が 1 次波応力範囲 $\Delta \sigma \mathrm{LF}(=60.1 \mathrm{MPa})$ より大きい場合は $\Delta \sigma_{\mathrm{ENL}}$ と $\Delta \sigma_{\mathrm{rf}}$ の頻度の差は小さい.

b) $\Delta \sigma_{\mathrm{ENL}}$ と $\Delta \sigma_{\mathrm{rf}}$ は最大でおおよそ $1.4 \Delta \sigma_{\mathrm{LF}}$ の值をとる.この 值は $\Delta \sigma_{L F}+\Delta \sigma_{H F}$ に概ね等しい.

c) $\Delta \sigma か ゙ \Delta \sigma_{\mathrm{LF}}$ より小さい場合は， $\Delta \sigma_{\mathrm{ENL}}$ がほとんど生じない 一方, $\Delta \sigma_{\mathrm{rf}}$ の発現頻度は $\Delta \sigma_{\mathrm{HF}}$ の約半分の值で極大を示す.

d) $\Delta \sigma_{E N L}$ と $\Delta \sigma_{\mathrm{rf}}$ は $\Delta \sigma_{\mathrm{LF}} よ り$ 小さい忘力範囲で発現頻度が大 きく異なるが， D ENF と $D_{\mathrm{rf}}$ の差は僅少である。

e) $\Delta \sigma_{\mathrm{HF}}<<\Delta \sigma_{\mathrm{LF}}$ である S3-2 を除いて $D_{\mathrm{LF}}$ は 0.5 より小さく最 小で 0.05 を示す.

f) $D_{\mathrm{ENL}}, \mathrm{D}_{\mathrm{rf}}$ は $\Delta \sigma_{\mathrm{HF}} / \Delta \sigma_{\mathrm{LF}}>1.0$ である（二次波が支配的な） $\mathrm{S} 1$ 3 を除いて $0.8 〜 1.6$ の值となる.

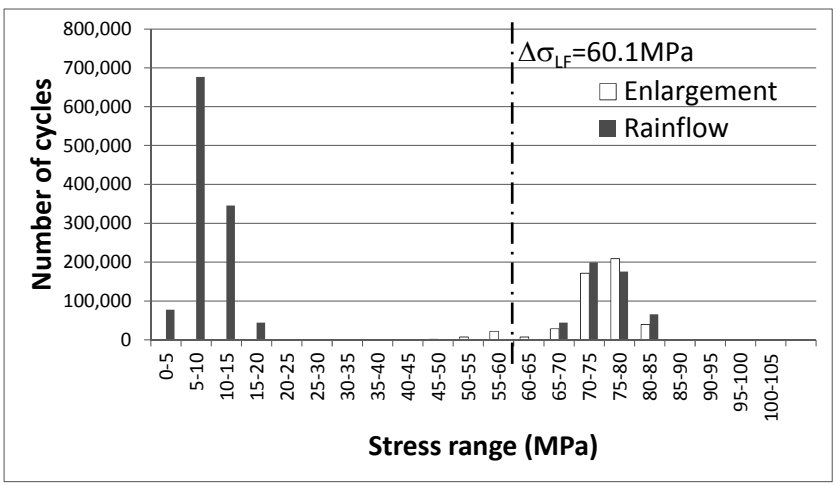

Fig. 14 Frequency distributions of nominal stress range calculated by enlargement and rainflow counting methods in a springing superimposed wave loading test (Case S3-1: $\Delta \sigma_{\mathrm{LF}}=60.1 \mathrm{MPa}, \Delta \sigma_{\mathrm{HF}} / \Delta \sigma_{\mathrm{LF}}=0.36$ ).

Table 3 Loading conditions, fatigue lives and accumulated damage of whipping superimposed wave loading tests.

\begin{tabular}{|l|r|c|c|c|c|r|r|}
\hline No. & $\begin{array}{r}\Delta \sigma_{\text {LF }} \\
(\mathrm{MPa})\end{array}$ & $\mathrm{Nb}$ & $\mathrm{D}_{\mathrm{LF}}$ & $\mathrm{D}_{\mathrm{ENL}}$ & $\mathrm{D}_{\mathrm{rf}}$ & $\begin{array}{c}\Delta \sigma_{\text {eq,ENL }} \\
(\mathrm{MPa})\end{array}$ & $\begin{array}{c}\Delta \sigma_{\text {eq,rf }} \\
(\mathrm{MPa})\end{array}$ \\
\hline WL_79HZ & 37.0 & $1.075 \mathrm{E}+06$ & 0.205 & 1.270 & 1.372 & 61.5 & 62.9 \\
\hline WH_79HZ & 37.0 & $5.525 \mathrm{E}+05$ & 0.105 & 0.539 & 0.605 & 57.3 & 59.2 \\
\hline WH_88HZ & 53.9 & $2.703 \mathrm{E}+05$ & 0.186 & 0.661 & 0.706 & 75.7 & 77.1 \\
\hline WH_97HZ & 65.2 & $2.088 \mathrm{E}+05$ & 0.275 & 1.036 & 1.055 & 93.7 & 94.2 \\
\hline
\end{tabular}

\section{3 ホイッピング重畳試験}

Fig. 4 に示す，ホイッピング振動発生用回転ハンマを搭載 した PBV 試験装置を使用して，ホイッピング重畳疲労試験 を実施した．試験条件を Table 3 に示す．ホイッピング成分 
振幅の大きさはハンマヘッド重量と起振機周波数（=ハンマ 回転周波数の $1 / 5)$ を変えて調整した，打撃記号 WH，WL は ハンマヘッド重量（H が大，L が小）を表し，2 林の数字は 起振機回転周波数の 10 倍の值を表す. ホイッピング周波数 は試験体の固有振動数 $28.5 \mathrm{~Hz}$ で不変なので, 起振周波数を 変えると一次波と二次波の周波数比も $2.94(9.7 \mathrm{~Hz}) \sim 3.61$ $(7.9 \mathrm{~Hz})$ の範囲で変化する. 各ケースの $\mathrm{D}_{\mathrm{rf}}, \mathrm{D}_{\mathrm{ENL}}, \mathrm{D}_{\mathrm{LF}}, \Delta \sigma_{\mathrm{eq}, \mathrm{rf}}$, $\Delta \sigma_{\text {eq,ENL }}$ の值を Table 3 に, D $\mathrm{D}_{\mathrm{rf}}, \mathrm{D}_{\mathrm{ENL}}, \mathrm{D}_{\mathrm{LF}}$ の比較を Fig. 15 に 示す.

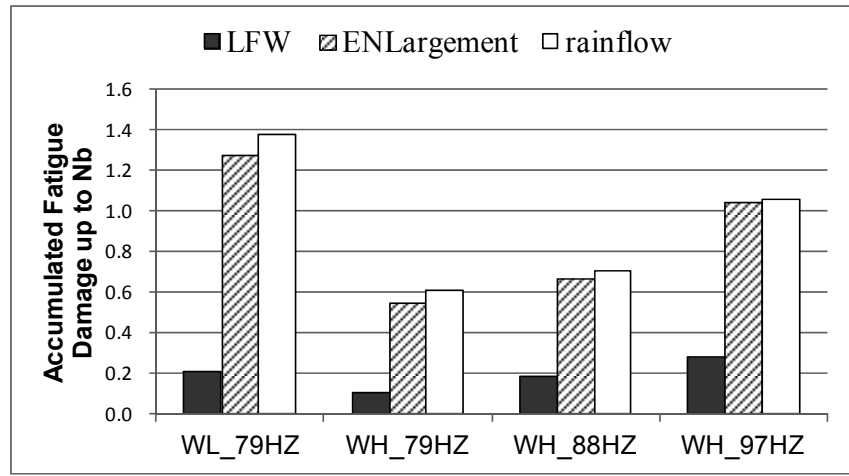

Fig. 15 Accumulated fatigue damage up to $\mathrm{N}_{\mathrm{b}}$ of out-of-plane gusset welded joints under whipping superimposed wave loadings calculated by LFW, enlargement and rainflow counting methods.

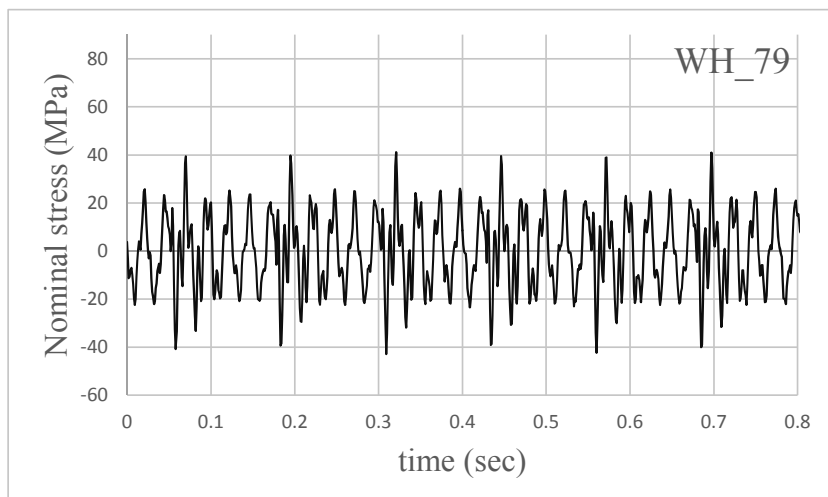

(a) Case WH-79HZ.

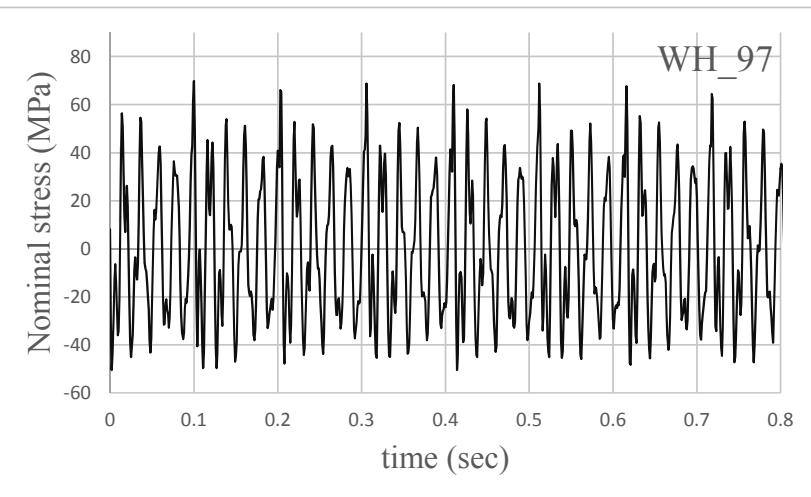

(b) Case WH-97HZ.

Fig. 16 Examples of nominal stress waveform measured in whipping superimposed loading tests.
ホイッピング重畳応力波形の最大応力範囲 $\Delta \sigma_{\mathrm{pp}, \max }$ と一次 波応力範囲 $\Delta \sigma_{\mathrm{LF}}$ の差 (二次波の最大有効応力範囲に相当) は 53.0MPa(WL_79HZ) 79.8MPa(WH_97HZ)の範囲の值を示し た.

重畳試験中に計測した公称応力波形の例を Fig. 16 に示す. 起振周波数が異なる 2 つ波形を示しているが, ホイッピン グが減衰するまでの間に生じる二次波形の数がやや少ない ことを除いて実船に作用する波形と類似の応力波形が生成 できている. Fig. 16 の波形について, rainflow 法, enlargement 法で計算した応力範囲 $\Delta \sigma$ の発現頻度分布を Fig. 17 に示す.

これらの図表では, スプリング重畳試験結果と同様な以下 の傾向が示されている :

a) $\Delta \sigma$ が1次波応力範囲 $\Delta \sigma_{\mathrm{LF}}(=37.0$ または $65.2 \mathrm{MPa})$ より大き

い場合は $\Delta \sigma_{\mathrm{ENL}}$ と $\Delta \sigma_{\mathrm{rf}}$ の頻度の差は小さい.

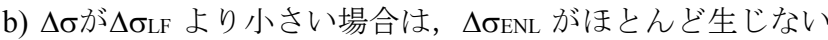
一方， $\Delta \sigma_{\mathrm{rf}}$ の発現頻度は極大を示す。

c) $\Delta \sigma_{\mathrm{ENL}}$ と $\Delta \sigma_{\mathrm{rf}}$ は $\Delta \sigma_{\mathrm{LF}}$ より小さい忘力範囲で発現頻度が大

きく異なるが，DeNF と D rf $の$ 差は僅少である。

d) $D_{\text {LF }}$ は最大で 0.3，最小で 0.1 以下になる.

e) $D_{\text {ENL }}, D_{\mathrm{rf}}$ は $0.55 〜 1.2$ の值となる.

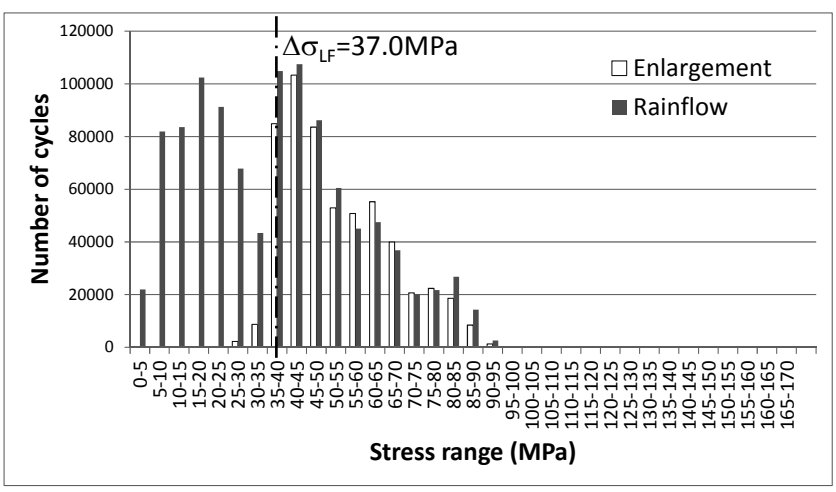

(a) Case $\mathrm{WH}-79 \mathrm{HZ}$

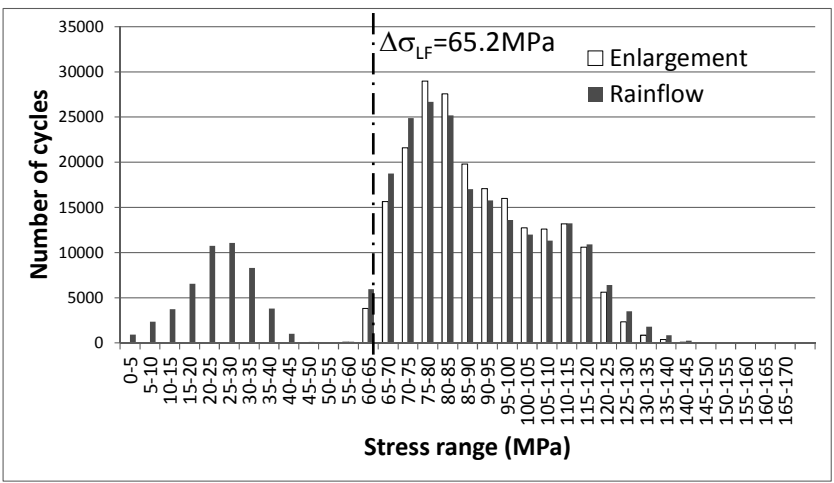

(b) Case WH-97HZ

Fig. 17 Frequency distributions of nominal stress range calculated by enlargement and rainflow counting methods in whipping superimposed wave loading tests.

4.2 節および本節では, スプリンギング重畳, ホイッピン グ重畳ともに LFW カウントを採用すると大幅に非安全側 
の疲労寿命推定となること, enlargement 法により計算した 疲労被害度は rainflow 法による計算値よりやや小さくなる がその差は小さく, 定常的に高周波重畳が生じる場合の被害 度は特殊な荷重条件を除いて 0.6 1.6 になったことが示さ れた。

この結果は, rainflow 法を用いると振幅増大のみ考慮した enlargement 法を用いた場合と概ね同じ被害度が計算される こと, および本研究の試験条件では, rainflow 法, enlargement 法の何れによっても, 定荷重振幅試験の SN 線図を用いれば 定常的に高周波重畳が生じる場合の疲労寿命を概ね推定す ることができることを示している.

\section{5. 疲労強度評価法の提案}

\section{1 高周波成分が常時重畳する場合}

4 章に示した高周波重畳疲労試験は全て定常的に高周波 が重畳した条件で実施した.まず，この場合についての疲労 強度評価法について論じる。

Fig. 18 に $\Delta \sigma_{\mathrm{eq}, \mathrm{rf}}$ (図中で rainflow と表示) または $\Delta \sigma_{\mathrm{eq}, \mathrm{ENL}}$ (図中で ENL と表示) と $\mathrm{N}_{\mathrm{b}}$ の関係を示す. 図には修正 Miner 則で計算した $\mathrm{D}=0.5, \mathrm{D}=1.0$ 相当の $\mathrm{SN}$ 線図と, $\Delta \sigma_{\text {eq,rf }}, \Delta \sigma_{\mathrm{eq}, \mathrm{ENL}}$ の双方について $\mathrm{P}_{\mathrm{S}}=50 \%$ 線図も示している. $\mathrm{P}_{\mathrm{S}}=50 \%$ 線図に相 当する疲労被害度 $\mathrm{D}_{\mathrm{Ps}=50 \%}$ は， $\Delta \sigma_{\mathrm{eq}, \mathrm{rf}}$ について $0.977, \Delta \sigma_{\mathrm{eq}, \mathrm{ENL}}$ について 0.899 である. $\Delta \sigma_{\mathrm{eq}, \mathrm{rf}}, \Delta \sigma_{\mathrm{eq}, \mathrm{ENL}}$ の差は小さい. スプ リンギング重畳試験結果は, $\Delta \sigma \mathrm{HF}>\Delta \sigma_{\mathrm{LF}}$ である場合を除いて, 定荷重振幅 SN 線図と同等か長寿命側にある. ホイッピング 重畳試験結果はややばらつきが大きく最も短寿命側で $\mathrm{D}=0.6$ を下回ったデータもある.

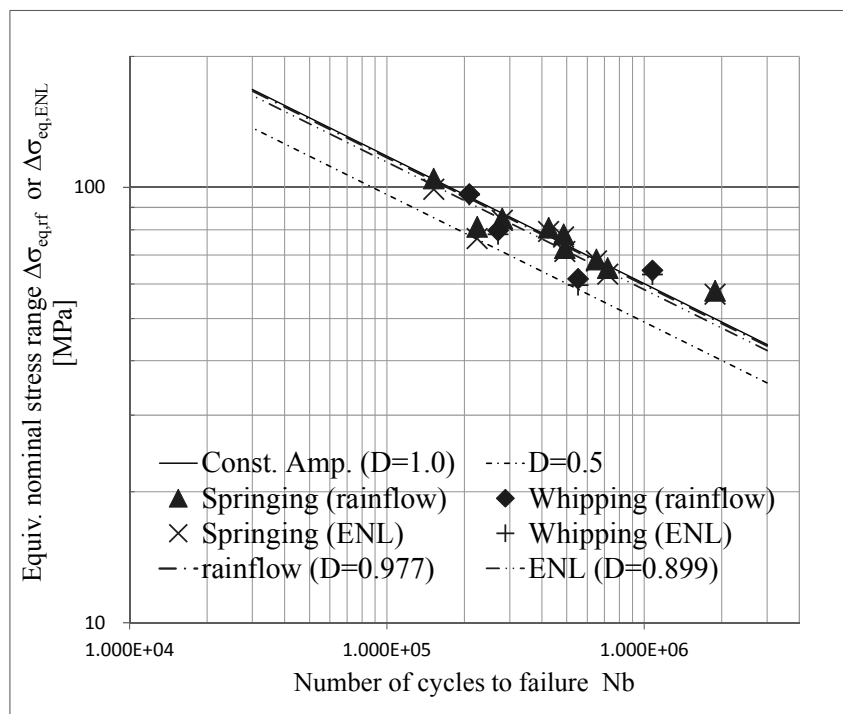

Fig. 18 The relationship between equivalent stress ranges determined by enlargement and rainflow stress counting methods and $\mathrm{N}_{\mathrm{b}}$ in constantly springing and whipping superimposed tests.

Fig. 18 は, 本研究の試験条件では, 定常的に高周波成分が 重畳する場合は, 定荷重振幅 SN 線図を重畳疲労試験結果の
Ps=50\%線図と一致するよう修正した上で, rainflow 法または enlargement 法と修正 Miner 則を用いることにより，近似的 に疲労寿命を推定できることを示している。

既存の SN 線図を用いて疲労寿命を推定する場合は, 高周 波重畳疲労試験を実施して, 定荷重振幅 SN 線図と高周波重 畳時 $\mathrm{Ps}=50 \% \mathrm{SN}$ 線図を取得して $\mathrm{DPs}_{\mathrm{P}=50 \%}$ を決定し，高周波重 畳時の疲労被害度に修正率 $1 / \mathrm{DPs}_{\mathrm{P}=50 \%}$ を乗じればよい. 本研究

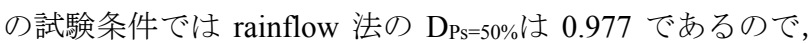
rainflow 法を使用する際は SN 線図の修正を省略できる.

この修正率は荷重条件により変化すると考えられる．Fig. 18 では，ホイッピング重畳波形とスプリンギング重畳波形 で異なる修正倍率を採用することが望ましいことも示され ている. 本報告で計算した修正倍率の一般の場合での有効性 は，さらなる実験により検証する必要がある.

Fricke $5^{15)}$, Karl $5^{16)}$ は，単軸負荷を受ける十字継手の 高周波重畳疲労試験を油圧式試験機により実施した. そして, IIW の疲労設計線図と同じ $\mathrm{m}=-0.333=-1 / 3.0$ を仮定して定荷 重疲労試験結果から得た SN 線図を用い，Haibach 修正を考 慮した rainflow 法により計算した破断時の被害度が $0.5 \sim 1.0$ の範囲でばらついたと報告している。一方，Fig. 18 では，定 荷重振幅試験の SN 線図 $(\mathrm{m}=-0.293=-1 / 3.41)$ を用い，修正 マイナー則と rainflow 法により計算した疲労被害度の平均 がほぼ 1.0 になったことが示されている。これは，本研究の 実験結果と異なり，Fricke ら ${ }^{15)}$, Karl ら 16)では rainflow 法を 用いても SN 線図の修正が必要であることを意味する。

Table 4 Loading conditions, fatigue lives and accumulated damage of intermittently springing superimposed loading tests.

\begin{tabular}{|l|c|c|r|c|r|r|}
\hline \multicolumn{1}{|c|}{ No. } & ns & \multicolumn{1}{c|}{ nc } & \multicolumn{1}{c|}{ ns/ntotal } & $\mathrm{Nb}$ & $\mathrm{D}_{\mathrm{rf}}$ & $\begin{array}{r}\Delta \sigma_{\text {eq,rf }} \\
(\mathrm{MPa})\end{array}$ \\
\hline S3-3 & \multicolumn{1}{c|}{-} & \multicolumn{1}{c|}{-} & - & $2.801 \mathrm{E}+05$ & 0.963 & 86.3 \\
\hline S3-3-25-2-1 & 35,000 & 105,000 & $25 \%$ & $9.355 \mathrm{E}+05$ & 3.180 & 86.0 \\
\hline S3-3-25-2-2 & 35,000 & 105,000 & $25 \%$ & $7.663 \mathrm{E}+05$ & 2.411 & 84.1 \\
\hline S3-3-50-2-1 & 70,000 & 70,000 & $50 \%$ & $5.195 \mathrm{E}+05$ & 1.880 & 87.6 \\
\hline S3-3-50-2-2 & 70,000 & 70,000 & $50 \%$ & $3.620 \mathrm{E}+05$ & 1.217 & 85.7 \\
\hline S2-3-25-2-1 & 35,000 & 105,000 & $25 \%$ & $6.841 \mathrm{E}+05$ & 4.300 & 103.0 \\
\hline S4-1-25-2-1 & 35,000 & 105,000 & $25 \%$ & $4.627 \mathrm{E}+05$ & 2.398 & 97.3 \\
\hline S4-2-25-2-1 & 35,000 & 105,000 & $25 \%$ & $2.960 \mathrm{E}+05$ & 0.964 & 85.0 \\
\hline
\end{tabular}

Table 5 Loading conditions, fatigue lives and accumulated damage of intermittently whipping superimposed loading tests.

\begin{tabular}{|l|c|c|r|r|r|r|}
\hline \multicolumn{1}{c|}{ No. } & ns & nc & ns/ntotal & Nb & $D_{\text {rf }}$ & $\begin{array}{r}\Delta \sigma_{\text {eq,rf }} \\
(\mathrm{MPa})\end{array}$ \\
\hline WH_88HZ & \multicolumn{1}{c|}{-} & - & - & $2.703 \mathrm{E}+05$ & 0.633 & 77.1 \\
\hline WH_88HZ-25-2-1 & 33,750 & 101,250 & $25 \%$ & $2.667 \mathrm{E}+05$ & 0.707 & 80.0 \\
\hline WH_88HZ-25-2-2 & 33,750 & 101,250 & $25 \%$ & $7.115 \mathrm{E}+05$ & 1.597 & 76.2 \\
\hline WH_88HZ-50-2-1 & 67,500 & 67,500 & $50 \%$ & $2.867 \mathrm{E}+05$ & 0.683 & 77.5 \\
\hline WH_88HZ-50-2-2 & 67,500 & 67,500 & $50 \%$ & $7.210 \mathrm{E}+05$ & 2.098 & 82.2 \\
\hline WH_88HZ-50-4-1 & 33,750 & 33,750 & $50 \%$ & $3.077 \mathrm{E}+05$ & 0.777 & 78.8 \\
\hline
\end{tabular}

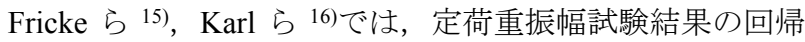
曲線が，IIW 設計線図 $(\mathrm{m}=-0.333)$ より緩やかな傾きを示す傾 向が示されている.よって, Fricke ら ${ }^{15)}$, Karl ら ${ }^{16)}$ では定荷 
重振幅試験結果より急な傾きの SN 線図で被害度が計算さ れた一方, 本研究では定荷重振幅 $\mathrm{SN}$ 線図 $(\mathrm{m}=-0.297)$ を直接 使用して被害度を計算した点に相違がある。この他にも, 被 害度計算法 (Haibach 修正と修正マイナー則) , 継手形式 (荷 重非伝達十字継手と角回し継手), 負荷形態 (引張りと曲げ), 応力比 $(0$ と-1），二次波歪速度（本研究の方が高速）等, 多くの相違がある.これらが複合的に影響して, Fricke ら ${ }^{15)}$, Karl ら 16) と本研究で異なる傾向の実験結果が得られたと推 定される.一般の船体構造に適用可能な疲労設計手法を開発 するためには, さらなる実験によって諸条件が疲労試験結果 および疲労寿命推定精度に与える影響を解明する必要があ ろ.

\section{2 高周波成分が間欠的に重畳する場合}

実船ではスプリンギング, ホイッピングは間欠的にしか発 生しない。間欠的な高周波重畳の影響を確認する目的で,

Table 2 および Table 3 の高周波重畳波形を用いて，間欠重畳 疲労試験を実施した。 各試験では, 重畳波形と, 重畳波形等 価応力範囲に等しい応力範囲の定振幅荷重を交互に作用さ せた. 等価応力振幅は式(2)-1 (rainflow 法)により計算した。

スプリンギング重畳については Table 2 の S3-3,S2-3，S41, S4-2 波形を負荷した. ホイッピング重畳については, Table 3 のWH $88 \mathrm{HZ}$ 波形を負荷した. 以下で， $\mathrm{N}_{\text {const }}$ を定常的に高 周波成分が重畳する場合の疲労寿命とする。一次波 $\mathrm{n}_{\mathrm{s}}$ 回分 の重畳波形と, それに続く $\mathrm{nc}$ 回の定振幅波形の組み合わせ を“荷重セット”とよぶ. $\mathrm{n}_{\mathrm{S}}+\mathrm{n}_{\mathrm{C}}$ を荷重セット総サイクル数 $\mathrm{n}_{\text {total }}$ とよぶ. 閒欠スプリンギング重冨疲労試験の試験条件を Table 4 に, 間欠ホイッピング重畳疲労試験の試験条件を Table 5 に示す. $\mathrm{n}_{\mathrm{S}} / \mathrm{n}_{\text {total }}$ は $1 / 4$ または $1 / 2$ とし, 1 セットの 一次波数 $\mathrm{n}_{\text {total }}$ が寿命 $\mathrm{N}_{\text {const }}$ の 25〜 50\%であるよう選んだ. 波 形識別名に続く 2 林の数字は比 $\mathrm{n}_{\mathrm{S}} / \mathrm{n}_{\text {total }}$ を，これに続く 1 桁 の数字は試験体番号を示す. 本節では疲労損傷度を rainflow 法により計算したので，5.1 節の結果より $\mathrm{SN}$ 線図の修正は 行わなかった。

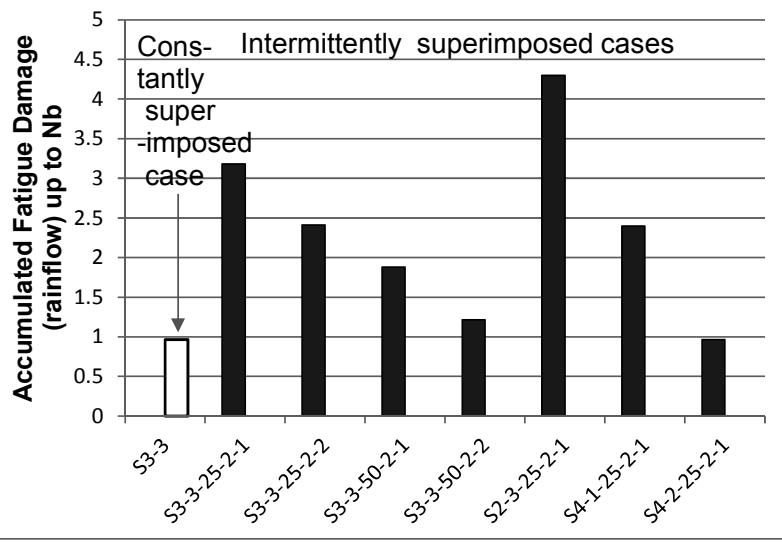

Fig. 19 Accumulated fatigue damage up to $\mathrm{N}_{b}$ of intermittently springing superimposed loading tests calculated by rainflow counting method.

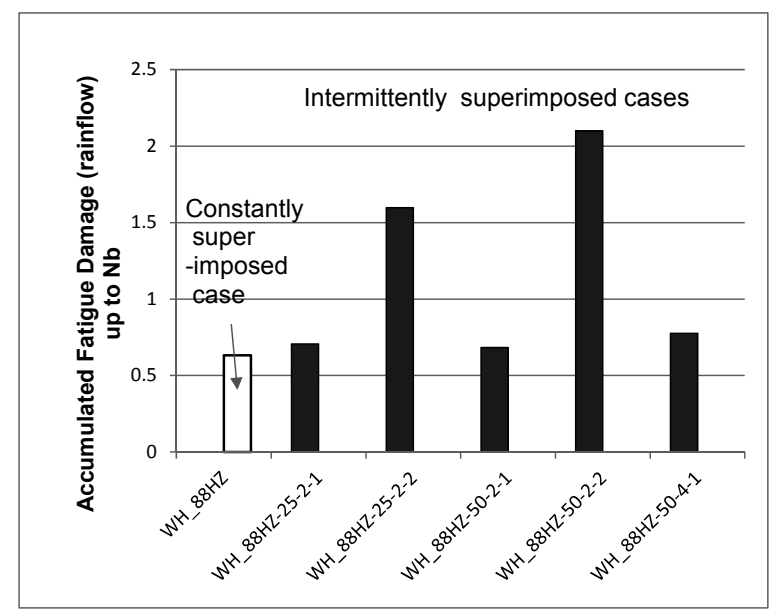

Fig. 20 Accumulated fatigue damage up to $\mathrm{N}_{\mathrm{b}}$ of intermittently whipping superimposed loading tests calculated by rainflow counting method.

間欠スプリンギング重畳試験結果の疲労寿命 $\mathrm{N}_{\mathrm{b}}$ 計測值, rainflow 法で計算した $\mathrm{N}_{\mathrm{b}}$ までの疲労被害度 $\mathrm{D}_{\mathrm{rf}}$, 式(2)-1 で計 算した等価応力範囲 $\Delta \sigma_{\text {eq,rf }}$ を Table 4 と Fig. 19 に示す. これ らの図表では，重畳波が間欠的に重畳する場合は，定常的に 重畳する場合より疲労寿命が大幅に延伸することが示され ている. 寿命延伸の程度と $\mathrm{n}_{\mathrm{S}}$ または $\mathrm{n}_{\mathrm{S}} / \mathrm{n}_{\text {total }}$ の関係は明瞭で はないが，被害度が最大になったのは条件 S2-3-25-2 の場合 で $\mathrm{D}_{\mathrm{rf}}=4.30$ に達した。

間欠ホイッピング重畳試験結果の $\mathrm{D}_{\mathrm{rf}}, \Delta \sigma_{\mathrm{eq}, \mathrm{rf}}$ を Table 5 と Fig. 20 に示す.これらの図表では，スプリンギング重畳の場 合ほど顕著でないが，重畳波が間久的に重畳する場合に，定 常的に重畳する場合と比較して疲労寿命が大幅に延伸する 場合があることが示されている．寿命延伸の程度と $\mathrm{n}_{\mathrm{s}}$ また は $\mathrm{ns} / \mathrm{n}_{\text {total }}$ の関係に一定の傾向は見いだせない。被害度が最 大になったのは条件 WI88-50-2-2 で $\mathrm{D}_{\mathrm{rf}}=2.098$ になっていた。

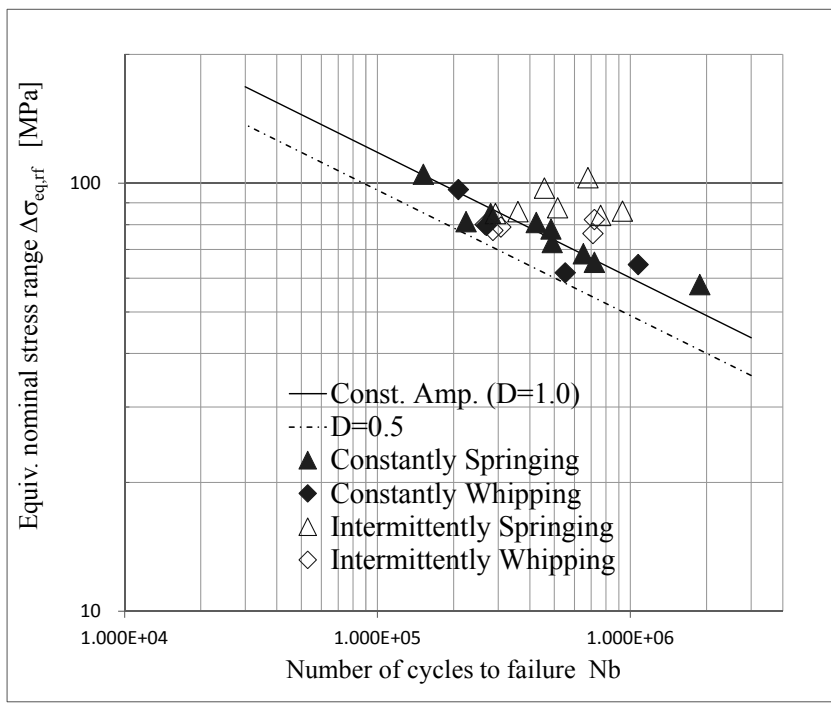

Fig. 21 The relationship between equivalent stress ranges determined by rainflow stress counting method and $\mathrm{N}_{\mathrm{b}}$ in intermittently springing and whipping superimposed tests. 
Fig. 21 に, 定常重畳試験, 間欠重畳試験の双方について式 (2)-1 で評価した $\Delta \sigma_{\text {eq,rf }}$ と $\mathrm{N}_{\mathrm{b}}$ の関係を示す. 図には定荷重振 幅試験の $\mathrm{D}=1.0$ 相当 $\mathrm{SN}$ 線図も示している. 図では間欠重畳 試験では定常重畳試験結果より大幅に長寿命側の $\mathrm{N}_{\mathrm{b}}$ が観察 されることが多かったことが示されている.

以上の結果は, 本研究の試験条件では, 高周波成分が間欠 的に重畳する場合は, スプリンギング重疊, ホイッピング重 畳の何れでも, 高周波成分が定常的に重畳する場合を対象に 5.1 節で提案した方法によって疲労寿命を推定すると, 過度 に安全側の推定結果が得られる場合が多いことを意味する。

Fricke ${ }^{15)}$, Karl ら 16)では, ホイッピング重畳が生じて いる 80 秒間の実船計測波形を繰返し負荷した場合と, 重畳 波形と非重畳波形が混在した 30 分間の実船計測波形を負荷 した場合の疲労寿命を比較した. そして, 破断時疲労被害度 の最小值が常時重畳波形で 0.5 を下回っていたのに対し, 非 重畳波形が混在した波形では 0.7 を上回ったと報告してい る. 寸なわち, 本研究の試験条件ほど顕著ではないが, 油圧 試験機による十字継手の単軸引張り疲労試験でも, 間欠重畳 の場合に常時重畳より疲労寿命が延伸する現象が観測され ていた.

\section{6. 今後の課題}

\section{1 高周波成分が定常的に重畳する場合}

本報告で実施した実験の応力波形は実船が受ける波形パ ターンを網羅しているとはいえない. 本報告ではホイッピン グ減衰の完了直後に衝撃荷重を与えることを繰返したが, 実 船ではホイッピング減衰終了から次回衝撃までの閏隔は変 動する. 高周波重畳時の疲労強度評価法を確立するためには, 減衰完了から次回衝撃までの間隔が变化した場合の寿命推 定精度を保証する必要がある。

5.1 節で提案した等価応力による疲労寿命評価では, スプ リンギング重畳時は定荷重試験と同等もしくはやや長寿命 でばらつきの小さい結果が得られた一方, ホイッピング重畳 時は定荷重試験と同等もしくは短寿命側でばらつきがやや 大きいとの結果を得た。すなわち, SN 線図修正倍率は応力 波形により相当程度変化した. この結果は, ホイッピング減 衰完了から次回衝撃までの時間を変化させた場合を含む, 本 報告で実施できなかった代表的応力波形パターン下で多数 の疲労試験結果を実施して疲労試験データを蓄積する必要 があることを示している.

\section{2 高周波成分が間欠的に重畳する場合}

5.2 節では，スプリンギング，ホイッピングの何れについ ても, 高周波成分が定常的に重畳する場合を対象に 5.1 節に 示した方法で疲労寿命を推定すると, 過度に安全側の推定值 が得られる場合が多いことが実験的に示された. しかし, 本 研究で実施した実験結果は, 寿命延伸と波形の特徵（重畳の 持続時間, 発現間隔) の関係を解明するのには量的に不十分 で, 閒欠的な重畳による寿命の延伸を定量的に推定する方法
論は確立できなかった.

実際に船舶が遭遇する, 間欠的に高周波成分が重畳する荷 重履歴に対して疲労寿命を精度よく推定するためには, 本研 究に引続いて, 実応力履歴の高周波重畳の発現頻度, 持続時 間等の特徵を再現できる応力波形を用いた多数の疲労試験 を実施して実験知見を蓄積する必要がある。

\section{7. 結言}

不平衡回転モータを用いた板曲げ振動疲労試験機に追加 回転モータまたは回転ハンマを装着して角回し溶接継手の スプリンギング・ホイッピング重畳疲労試験を実施した. 疲 労試験中の応力波形を rainflow 法および新たに開発した enlargement 法により疲労損傷度を評価し，定常的に高周波 重畳荷重を受ける溶接継手の疲労寿命推定法について考察 した.さらに, 高周波重畳波形と非重畳波形を交互に負荷す る疲労試験を実施し, 高周波重畳が定常的に生じる場合に有 効な疲労寿命推定法の間欠重畳波形における有効性を調心 た．本研究で得られた知見は以下のように要約できる：

(1) 本研究の試験条件では rainflow 法を用いると振幅増大の み考慮した enlargement 法を用いた場合と概ね同じ被害度が 計算された。

（2）本研究の試験条件では，定常的に高周波成分が重畳する 場合は，定荷重振幅 SN 線図を重畳疲労試験等価応力 SN 線 図の $\mathrm{Ps}_{\mathrm{s}}=50 \%$ 線図と一致するよう修正した上で，rainflow ま たは enlargement 応力カウントと修正 Miner 則を用いること により近似的に疲労寿命を評価できる.

(4) 本研究の試験条件では，高周波成分が間欠的に重畳する 場合に, 前項で高周波成分が定常的に重畳する場合を対象に 提案した方法で疲労寿命を推定すると, 過度に安全側の推定 結果が得られる場合が多い。

(5) 実際に船舶が遭遇する応力履歴に対して合理的に疲労 寿命を推定するためには, 本研究に引続いて, 実応力履歴の 高周波重畳の発現頻度, 持続時間等の特徵を再現できる応力 波形を用いた多数の疲労試験を実施して, 実験知見を蓄積す る必要がある。

\section{謝 辞}

本研究は（財）日本海事協会・大阪大学・ジャパンマリ ンユナイテッド（株）の共同研究の一部として実施した．実 験にあたっては，片岡福彦氏（ジャパン・マリンユナイテッ ド（株）），篠原冴企氏（研究当時大阪大学工学研究科）, 大島啓輔君, 高橋一広君 (大阪大学工学研究科) にご助力い ただいた. 疲労試験装置の開発にあたっては, 山田健太郎博 士（名古屋大学名誉教授）, 石川敏之博士（研究当時京都大 学工学研究科, 現関西大学) から貴重なご教示を賜った. 打 撃装置の設計製作では，佐藤雄輔氏（大和鉄工株式会社）に ご助力いただいた. 本論文の終わりにあたり関係各位に厚く 御礼申し上げる. 
参 考 文 献

1) Storhaug, G., Moe, E., Holtsmark, G.: Measurements of Wave Induced Hull Girder Vibrations of an Ore Carrier in Different Trades, J. Offshore Mechanics and Arctic Engineering, 129, pp. 279-289, 2007.

2) Storhaug, G., Moe, E.: Measurements of Wave Induced Vibrations Onboard a Large Container Vessel Operating in Harsh Environment, Proc. PRADS2007, pp. 64-72, 2007.

3）青木逸朗, 初野耕三, 中村宏, 国尾武: 重畳微小波をもつ 繰返し荷重による疲れの研究（第 1 報, 微小応力発生装 置の試作とそれを用いた二,三の疲れ試験結果）, 日本機 械学会論文集, 31, 222, pp.189-193, 1965.

4) 高杉俊二, 堀川武, 恒成利康, 中村宏: 重畳波および組合 せ荷重波形下の疲労試験結果と寿命推定，材料, 32, 356, pp.11-17, 1983.

5) 高杉俊二, 堀川武, 恒成利康, 中村宏 : 重畳波形下の推定 疲労寿命に及ぼす影響因子と寿命推定法の検討, 材料, 33, 371, pp. 13-19, 1984.

6) 菲原和典, 神保昇二, 伊藤悟郎 : 重畳波応力による疲労 被害および最適応力頻度表示法の研究, 自動車技術, Vol. 22, No. 5, pp.390-396, 1968.

7) 山本成 : ディーゼル機関燃焼室壁まわりの強度(その 2), 日本舶用機械学会誌, 11, 5, pp.340-348, 1976.

8) 北村欧, 杉村忠士, 中山伸, 廣田一博 : 高一低周波重畳 応力作用下における疲労き裂伝播試験の一考察, 日本 船舶海洋工学会講演会論文集, 14,pp.13-16, 2012.

9) 角洋一: 疲労き裂成長に及ぼすスラミング・ホイッピン グ応力の影響, 日本船舶海洋工学会講演会論文集, 14 , pp.9-12, 2012.

10) Sumi, Y. : Fatigue crack propagation in marine structures under seaway loading, International Journal of Fatigue, Vol.58, pp.218-224, 2014.
11) Gotoh, K., Matsuda, K. and Kitamura, O. : Numerical Simulation of Fatigue Crack Propagation Under Superposed Loading Histories with Two Different Frequencies, Proc. Hydroelasticity 2012, pp. 287-297, 2012.

12) 後藤浩二，松田和貴 : 複数周波数成分を有する重畳応力 条件下における疲労き裂伝播挙動解析, 日本船舶海洋工 学会論文集, 17, pp.74-81, 2013.

13) Matsuda, K. and Gotoh, K. : Simulation of Fatigue Crack Propagation under Simulated Whipping Loading Arising in Hull Structures, Proc. OMAE 2013, Paper OMAE2013-10985, 2013.

14) 角洋一，高碕怜史，早川銀河：小振幅荷重を重畳した繰 り返し荷重下の疲労き裂伝播について，日本船舶海洋工 学会講演会論文集，16，pp.519-522，2013。

15) Fricke, W., Paetzold, H.: Experimental Investigations on Fatigue Damage of Ship Structures Caused by Whipping Stresses, Proc. PRADS2013, pp. 465-470, 2013.

16) Kahl, A., Fricke, W., Paetzold, H., Selle, H.: Whipping Investigations Based on Large-Scale Measurements and Experimental Fatigue Testing, Proc. ISOPE2014, pp. 774-781.

17) Yamada K., "Some New Approaches to Fatigue Evaluation of Steel Bridges", Steel Structures, No. 6, 2006, pp. 3-10.

18) Toyoda K., Matsumoto, T., Yamamoto, N., Terai, K. "Simplified Fatigue Assessment Considering the Occurrence Probability of Hydro-Elastic Response in Actual Sea State Conditions", Proceedings of Hydroelasticity 2012, 2012, pp. 367-375.

19) ASTM E 1049-85, Rainflow Counting Method, 1987.

20) 石川敏之，山田健太郎，柿市拓巳，李番，”ICR 処理に よる面外ガセット溶接継手に発生した疲労き裂の寿命 向上効果”，土木学会論文集 A，Vol.66, No.2，2010, pp. 264-272. 